\title{
Effect of oral $\alpha$-tocopherol and zinc on plasma status, IGF-I levels, weight gain and immune response in young calves
}

\author{
J. Sehested ${ }^{1,4}$, C. Jørgensen ${ }^{1}$, S.B. Mortensen ${ }^{1}$, S.K. Jensen ${ }^{1}$, \\ M. Vestergaard ${ }^{1}$, P. Koch ${ }^{2}$, G. Jungersen ${ }^{3}$ and L. Eriksen ${ }^{2}$ \\ ${ }^{1}$ Department of Animal Nutrition and Physiology, Danish Institute of Agricultural Sciences, \\ Research Centre Foulum, P.O. Box 50, DK-8830 Tjele, Denmark \\ ${ }^{2}$ Department of Animal Science, Internal Medicine, The Royal Veterinary and Agricultural University \\ Dyrlaegevej 88, DK-1870 Frederiksberg C, Denmark \\ ${ }^{3}$ Department of Veterinary Diagnostics and Research, Danish Institute for Food and Veterinary Research \\ Bülowsvej 27, DK-1790 Copenhagen V, Denmark
}

\begin{abstract}
Thirty newborn calves were supplemented with $\alpha$-tocopherol (vit. E) $(n=10)$, zinc $(\mathrm{Zn})(\mathrm{n}=10)$ or nothing (control) $(n=10)$ for 8 weeks. All calves were vaccinated against tetanus at week 5. Plasma $\mathrm{Zn}$ and $\alpha$-tocopherol were significantly increased in the $\mathrm{Zn}$ and vit. E groups, respectively. Plasma IGF-I levels generally increased from birth to week 8, but were not affected by Zn or vit. E. Daily weight gain was highest in the $\mathrm{Zn}$ group, but this was not related to an increased IGF-I level. The vit. E group responded earlier than the $\mathrm{Zn}$ and control groups to the tetanus vaccination.
\end{abstract}

KEY WORDS: calves, $\alpha$-tocopherol, zinc, immune response, growth, IGF-I

\section{INTRODUCTION}

Calves are born with low or moderate levels of zinc $(\mathrm{Zn})$ and without detectable level of vitamin E ( $\alpha$-tocopherol) in plasma and tissues. However, vitamin $\mathrm{E}$ and $\mathrm{Zn}$ play an important role in development and maturation of the immune system. Furthermore $\mathrm{Zn}$ is important in order to maintain normal growth and organ development (Shankar and Prasad, 1998; Underwood and Suttle, 1999; Hatfield et al., 2002). The Zn and $\alpha$-tocopherol (vit. E) contents of whole milk are often below the recommended level of $40 \mathrm{mg}$ and $50 \mathrm{IU}$ per kg dry matter (DM), respectively (NRC,

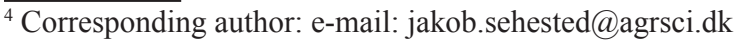


2001). Early signs of $\mathrm{Zn}$ deficiency are reduced feed intake and growth. In piglets serum IGF-I (Insulin-like Growth Factor I), feed intake and weight gain increased with increasing dietary $\mathrm{Zn}$ (Carlson et al., 2004).

The objectives of the present experiment were to study the effect of supplementary $\mathrm{Zn}$ and $\alpha$-tocopherol on plasma levels, growth rate, feed intake, IGF-I and immune response in young calves.

\section{MATERIAL AND METHODS}

Thirty newborn Holstein calves were randomly allocated in three experimental groups: control, vit. E and Zn, for an experimental period of 8 weeks. All calves were given colostrum $(2 \times 3 \mathrm{~L}$ per day $)$ the first three days of life. From day four the basal diet was whole milk, $2 \times 3$ L per day until day 14 , and thereafter $2 \times 4$ L per day. All calves had free access to water and hay. Starter was allocated $a d$ libitum up to max $0.5 \mathrm{~kg}$ per day. From day four, calves in the vit. E group were supplemented with $2 \times 250$ IU $\alpha$-tocopherol (Natur E Micelle, Pharmalett) in the milk per day, whereas the $\mathrm{Zn}$ group was supplemented with $0.35 \mathrm{mM} \mathrm{Zn}$ in the milk (180 mg Zn per kg milk DM as $\mathrm{ZnSO}_{4}$ ). At day 35 all calves were vaccinated against tetanus (Equilis Tetanusvaccine Vet. Intervet).

Individual feed intake and weight gain was registered. Plasma IGF-I, $\alpha$ tocopherol, $\mathrm{Zn}$ levels and anti-tetanus antitoxin antibodies levels in serum were measured during the experimental period (DEFT, 1971; Frystyk et al., 1995; Kristiansen et al., 1997; Jensen et al., 1999). The effect of treatment on weight gain and plasma levels of $\mathrm{Zn}, \boldsymbol{\alpha}$-tocopherol and IGF-I were analysed using General Linear Models Procedure (SAS Institute Inc., 1999). The effect of treatment on antibodies was analysed by GraphPad Prism 4.00 software.

\section{RESULTS AND DISCUSSION}

Two calves were discarded from the dataset due to general and unspecified poor growth. The natural content of $\alpha$-tocopherol in milk and starter was 0.74 and $102 \mathrm{mg}$ per $\mathrm{kg}$ feed, respectively. The natural content of $\mathrm{Zn}$ in milk and starter was 29 and $77 \mathrm{mg}$ per $\mathrm{kg}$ feed DM, respectively. Table 1 shows that plasma $\mathrm{Zn}$ was at a normal to high level in the control group (Underwood and Suttle, 1999; NRC, 2001), but was increased to a significantly higher level in the $\mathrm{Zn}$ group. Plasma $\alpha$-tocopherol was at a low level in the control group, but was increased to a significantly higher level in the vit. E group. The plasma $\mathrm{Zn}$ and $\alpha$-tocopherol levels were raised within two and one weeks of supplementation, respectively (data not shown). Plasma IGF-I levels generally increased from birth to week 8, but were not affected by $\mathrm{Zn}$ or $\alpha$-tocopherol supplementation (Table 1). Daily 
Table 1. Feed intake, growth rate and plasma levels of Zn, $\alpha$-tocopherol and IGF-I ( \pm SEM)

\begin{tabular}{|c|c|c|c|c|c|c|c|c|c|}
\hline \multirow{2}{*}{ Group } & \multicolumn{2}{|c|}{$\begin{array}{l}\text { Feed intake } \\
\text { g DM day }^{-1}\end{array}$} & \multirow{2}{*}{$\begin{array}{l}\text { Weight } \\
\text { gain } \\
\text { g day }^{-1}\end{array}$} & \multicolumn{2}{|c|}{$\begin{array}{c}\text { Plasma } \\
\text { Zn mg l}^{-1}\end{array}$} & \multicolumn{2}{|c|}{$\begin{array}{l}\text { Plasma } \alpha \text {-tocoph. } \\
\mathrm{mg} \mathrm{l}^{-1}\end{array}$} & \multicolumn{2}{|c|}{$\begin{array}{c}\text { Plasma IGF-I } \\
\mathrm{ng} \mathrm{ml}^{-1}\end{array}$} \\
\hline & milk & starter & & & & week 1 & & week 1 & week 8 \\
\hline ont & 971 & 148 & 20 & $1.8 \pm 1.6$ & $17+0$ & $.6 \pm 0.3$ & & $12 \pm 32$ & $184 \pm 52$ \\
\hline Vit. E & 958 & 155 & $777+8$ & $1.1 \pm 0.5$ & $1.7 \pm$ & 0.2 & & $103 \pm 27$ & $192 \pm 58$ \\
\hline $\ln$ & 970 & 177 & $856 \pm 72^{a}$ & $1.6 \pm 1.4$ & $2.7 \pm 0.4^{\mathrm{a}}$ & $0.6 \pm 0.3$ & $0.6 \pm 0.3^{b}$ & $117 \pm 35$ & $184 \pm 52$ \\
\hline
\end{tabular}

Different letters in superscript indicate significant difference between groups $(\mathrm{P} \leq 0.05)$

weight gain was highest both absolute and per MJ net energy intake (data not shown) in the Zn group, but this was apparently not related to an increased IGF-I level in this group. Weight gain in the $\mathrm{Zn}$ group was significantly different from the vit. E group $(\mathrm{P}=0.02)$, whereas the difference from the control group was nonsignificant $(\mathrm{P}=0.13)$. The $\alpha$-tocopherol content in plasma measured at week 1 was below the level of 3-4 $\mathrm{mg} \mathrm{l}^{-1}$ considered adequate for optimal immune function (Reddy et al., 1986). This low level was maintained throughout the experimental period for the control group and the $\mathrm{Zn}$ group, whereas plasma $\alpha$-tocopherol in the calves supplemented with extra vitamin E was raised to 6-8 $\mathrm{mg} \mathrm{l}^{-1}$.

The response to the tetanus vaccination was followed by measurement of antitetanus antitoxin antibodies (Figure 1). Two calves in the vit. E group and one calf in the $\mathrm{Zn}$ group had for unknown reasons no measurable antibody response to the vaccination, and these calves were excluded from the dataset. Figure 1 shows that the vit. E group responded with higher OD (optical density) values than the $\mathrm{Zn}$ and control groups. The effect of vit. E supplementation on the development of antibodies was significantly different from that of the control group $(\mathrm{P}=0.034)$

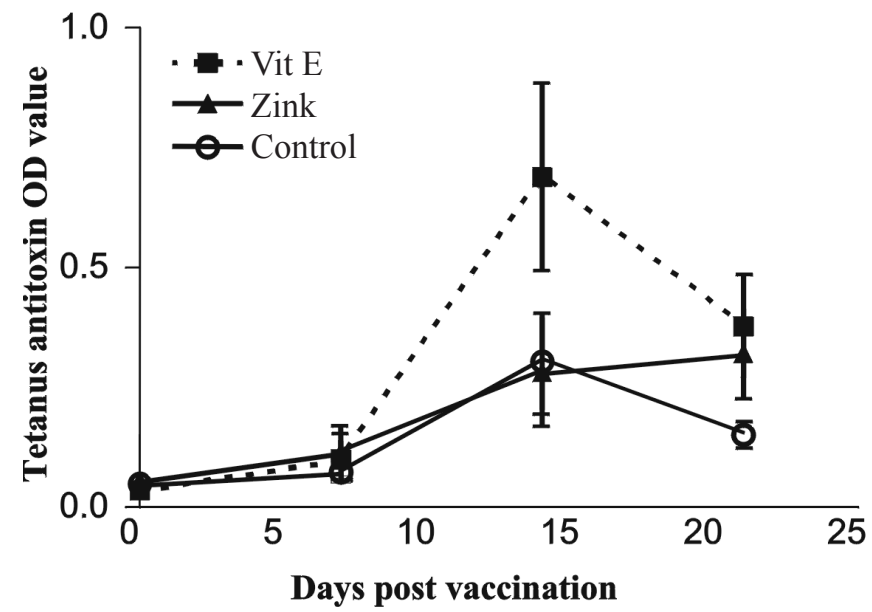

Figure 1. Development of antibodies in serum (optical density = OD) against tetanus toxin subsequent to vaccination 
and the $\mathrm{Zn}$ group, while no effect of $\mathrm{Zn}$ supplementation was observed relative to the control group.

\section{CONCLUSIONS}

The plasma $\mathrm{Zn}$ and $\alpha$-tocopherol levels in the 2 days old calves were normal and low, respectively, but were significantly raised by oral supplementation with $\mathrm{ZnSO}_{4}$ and $\alpha$-tocopherol in the milk, respectively. Weight gain and feed conversion tended to be highest in the $\mathrm{Zn}$ supplemented group, but this was apparently not related to plasma IGF-I levels. Following tetanus vaccination the vit. E group responded with significantly higher levels of antibodies than the $\mathrm{Zn}$ and control groups. While the selected immune parameter was significantly effected by $\alpha$ tocopherol supplementation, this was not related to changes in IGF-1 levels or increased weight gain.

\section{REFERENCES}

Carlson D., Poulsen H.D., Vestergaard M., 2004. Additional dieary zinc for weaning piglets is associated with elevated concentrations of serum IGF-I. J. Anim. Physiol. Anim. Nutr. 87, 1-8

DEFT, 1971. Kommissionens første direktiv af 15. juni 1971 om fastsættelse af fællesskabsanalysemetoder til den officielle kontrol af foderstoffer. De Europæiske Fællesskabers Tidende, L155/ $13,426-427$

Frystyk J., Dinesen B., Ørskov H., 1995. Non-competitive time-resolved immunofluorometric assays for determination of human insulin-like growth factor I and II. Growth Regulat. 5, 169176

Hatfield P.G., Robinson B.L., Minikhiem D.L., Kott R.W., Roth N.I., Daniels J.T., Swenson C.K., 2002. Serum alpha-tocopherol and immune function in yearling ewes supplemented with zinc and vitamin E. J. Anim. Sci. 80, 1329-1334

Kristiansen M., Aggerbeck H., Heron I., 1997. Improved ELISA for determination of anti-diphteria and/or anti-tetanus antitoxin antibodies in sera. APMIS 105, 843-853

NRC, 2001. Nutrient Requirements of Dairy Cattle. $7^{\text {th }}$ revised Edition. National Academy Press, Washington, DC

Reddy P.G., Morill J.L., Minocha H.C., Morill A.D., Dayton A.D., Frey R.A., 1986. Effect of supplemental vitamin E on the immune system of calves. J. Dairy Sci. 69, 164-171

SAS Institute Inc., 1999. SAS Version eight, SAS OnlineDoc, SAS Institute Inc., Cary (USA)

Shankar A.H., Prasad A.S., 1998. Zinc and immune function: the biological basis of altered resistance to infection. Amer. J. Clin. Nutr. 68, 447S-463S

Underwood E.J., Suttle N.F., 1999. The Mineral Nutrition of Livestock. CAB International, Wallingford 